\title{
Career adaptability of parents of children with autism spectrum disorder
}

\author{
Nurten Karacan Ozdemir ${ }^{1}$ (D) Muharrem $\operatorname{Koç}^{1}$ (I)
}

Accepted: 17 December 2021

(c) The Author(s), under exclusive licence to Springer Science+Business Media, LLC, part of Springer Nature 2021

\begin{abstract}
This descriptive phenomenological study examines career adaptability of parents of children with Autism Spectrum Disorder (ASD). Participants include 30 parents (18 fathers and 12 mothers; 6 of them were couples) ranging in age from 26 to 45 years, selected by a purposive sampling method. The semi-structured interview form developed by the researchers based on the Career Construction Theory was used to collect data after receiving expert verification on the questions. In addition, to triangulate data sources, the Participant Feedback Form filled by the participants on the day following the interview and the Researcher Diary filled by the interviewer during the data collection process were utilized. Colaizzi's seven-step method was followed to analyze the data. Four major domains emerged, highlighting traumas/changes in work-life after ASD, career adaptability, influences of COVID-19 pandemic, and post-interview awareness of this particular sample. Results from the study highlighted looking ahead, being persistent, career decision-making, career-exploration accompanied by some expectations such as more time, income and flexibility, and coping skills build upon the ASD, along with postponement and abandonment of previous career goals, alteration of future career plans, and lack of self-exploration. The results contributed to the theory by providing evidence for career adaptability of parents of children with individual differences, including career adaptability resources and needs. Findings also implied the need for interventions to foster career adaptability skills of parents regarding looking ahead in a positive way, decision-making, self-exploration, and coping with career barriers and difficulties.
\end{abstract}

Keywords Career adaptability · Autism Spectrum Disorder · Parents · Qualitative Research · COVID-19 pandemic

Autism Spectrum Disorder (ASD) is a neurodevelopmental disorder that is characterized by inadequate social communication and social interaction and manifests itself through repetitive, obsessive behaviors, restricted interests and activities (American Psychiatric Association [APA], 2013). ASD affects the lives of all family members (Duarte et al., 2005; Hayes \& Watson, 2013), implying the beginning of a difficult life for them (Pelchat et al., 2003). The relevant literature indicated that diagnosis of ASD affects parents in many ways (Walsh et al., 2013); after diagnosing ASD in children, parents experience stress and anxiety (Liao \& Wei, 2011); spouses diverge from each other (Orsmond \& Seltzer, 2007); conflicts emerge between spouses (Hartley et al., 2017); their marriage is broken (Hartley et al., 2010); parents blame each other and the process might result in

Nurten Karacan Ozdemir

karacan.nurten@gmail.com

1 Education Faculty, Guidance and Psychological Counseling, Hacettepe University, Ankara, Turkey 06800 divorce (Freedman et al., 2012). It was also emphasized that parents might be excluded by society (Cavkaytar et al., 2008; Lecavalier et al., 2006) and might isolate themselves from society (İkizoğlu, 2005).

The need for intensive and special care services for children with ASD requires that all individuals in a family within a systemic approach (Gladding, 2014) make arrangements in their own lives (Turnbull et al., 2015). Due to the needs of children, parents try to organize their working lives according to the needs and behaviors of children (Whiting, 2014); have difficulty in maintaining the balance between working life and family functioning (Lewis et al., 2000) and difficulties in maintaining employment (Myers et al., 2009). At this point, it might be seen as a problem that both parents continue to work full-time (Rosenzweig et al., 2008), and it is expected that one of the parents will end or disrupt his/her career for their child's care (Rosenzweig et al., 2002). Montes and Halterman (2008) reported that parents of children with ASD were more likely to change their job, quit their job or not take a job, compared with parents of 
children with typical development. Similarly, it was reported that mothers with children with ASD experience significant career disruption and most of them may not work outside because of the children's care. On the other hand, those who have a job might experience leave of absence, reduction in work hours and turning down promotion opportunities and earn less income (e.g., Baker \& Drapela, 2010; Cidav et al., 2012; Montes \& Halterman, 2006).

Considering that ASD is usually diagnosed in early childhood and described as a lifelong condition, it can be said that parents should make a lifelong effort against the problems they will experience (Shattuck et al., 2007). Accordingly, the existing literature underlined that parents of children with ASD are affected by numerous negative experiences, compared with parents of children with other groups of special needs (Meral \& Cavkaytar, 2012; Walsh et al., 2014). Besides unemployment and underemployment problems, factors such as uncertainties, changes and competition in the world of work could be added to various problems such as education, health and the future of their children as well as financial problems. At this point, it can be said that they need regulatory skills for their lives and careers such as flexibility, autonomy and tolerance, hence career adaptability, to handle changes, challenges, and uncertainties in the world of work as well as work traumas such as job loss (Ginevra et al., 2018).

\section{Career Adaptability}

Within the perspective of Career Construction Theory (CCT; Savickas, 1997, 2005), career adaptability (CA) is defined as "individual's resources for coping with current and anticipated tasks, transitions and traumas in their occupational roles that, to some degree large or small, alter their social integration" (Savickas \& Porfeli, 2012, p. 662). Therefore, it refers to the capacity of individuals to plan their career and adapt to unforeseen situations (Savickas, 2005). Career adaptability, as a multidimensional construct, has four basic components: concern, control, curiosity, and confidence (Savickas, 2005; Savickas \& Porfeli, 2012). Concern refers to individuals' interest, attention and preparation for the future (Savickas, 2005). It is stated that individuals with high career concern have a positive view of the future and future orientations (Savickas, 2005), high levels of hope and optimism (Youssef \& Luthans, 2007), and high planning skills (Pajic et al., 2018). Low concern is associated with career indifference and carelessness, planlessness, and pessimism about the future (Savickas \& Porfeli, 2012). Control reflects taking personal responsibility for individuals' own career by showing persistence, perseverance and consistency (Savickas, 2005). Individuals having high control can make career decisions, try to fulfill career development tasks, and believe that they have control over their future (Savickas, 2005). Low level of control is associated with career indecision, which causes individuals to postpone career related issues and a general uncertainty in their career (Hartung \& Cadaret, 2017). Curiosity is the tendency of individuals to explore the environment to obtain information about themselves and their environment through educational and career alternatives. It was stated that individuals with high curiosity are more successful in being proactive and open to new experiences (Zacher et al., 2015), getting information about the world of work (Savickas, 2005), and discovering new career options (Hirschi, 2010). Low curiosity causes individuals to have unrealistic information about themselves and their work life, limit their career options, and create unrealistic expectations for the future (Savickas \& Porfeli, 2012). Confidence, lastly, means that individuals have a sense of self efficacy to overcome difficulties and obstacles in their career. Individuals with high confidence can cope with the problems in their career (Bimrose \& Hearne, 2012; Klehe et al., 2011) and are aware of their own limits (BuyukgozeKavas et al., 2015), yet people with low career confidence have difficulties in taking action or struggling with the obstacles they encounter (Savickas, 2013).

The previous studies showed that career adaptability was associated with adapting responses such as career planning, searching and career decision making (Hirschi et al., 2015; Johnston, 2016). In addition, career adaptability influenced individual and employment outcomes such as work performance (Zacher, 2014a, 2014b), work engagement (Xie et al., 2016; Yang et al., 2019), negative job stress (Johnston et al., 2013), job satisfaction (Coetzee \& Harry, 2014; Fiori et al., 2015), employability (McArdle et al., 2007), promotability (Chan et al., 2016; Sibunruang et al., 2016), income (Guan et al., 2015), and career success (Ocampo et al., 2018). Considering the importance of adapting responses and adaptation results predicted by career adaptability in career life of people, it is essential to examine adaptability resources -career adaptabilities- of parents of children with ASD, yet seldom researched (e.g., Ginevra et al., 2018).

\section{Turkish Context and the Rationale for the Study}

The employment rate of 15-64 age groups in Turkey 47.7\%; employment rates by gender were reported as $28.7 \%$ for women and $63.1 \%$ for men (TurkStat, 2020a). $16.7 \%$ of the employed were in agriculture, $20.9 \%$ in industry, $6.2 \%$ in construction and $56.2 \%$ in the service sector. The unemployment rate was reported as $13.1 \%$ and the rate of unregistered workers as $29.7 \%$. When looking at unemployment rates in detail, it can be seen that $27.7 \%$ of individuals were unemployed for one year or more (TurkStat, 2020a). Employees 
reported some work-related problems such as wage amount (23\%), difference between wages (15.5\%), working conditions $(15 \%)$, not paying wages on time $(6.6 \%)$, underpayment (4.3\%) and taking one or two hours for personal or family matters during working hours (9.6\%) (TurkStat, 2020b). Comparing with international statistics, Turkey had longer working hours; weekly $9.3 \mathrm{~h}$ and $11.9 \mathrm{~h}$ more than European countries and the United States, respectively (EuroStat, 2018 ) and $47.5 \%$ the disparity of employment on behalf of underprivileged groups (eg, individuals with disabilities; Organization for Economic Co-operation and Development [OECD], 2017).

It could be said that, in Turkey, the statistics available for individuals with disabilities are far from reflecting the current status. Based on the 30th article of the Labor Law numbered 4857; employers are obliged to employ a number of workers with disabilities equal to $3 \%$ of the number of workers they employ in private sector workplaces where they employ fifty or more workers, and $4 \%$ in public workplaces. The jobs should be suitable for professions, physical and mental conditions of individuals with disabilities. According to Survey on Problems and Expectations of People with Disabilities (TurkStat, 2010), the employment rate of individuals with disabilities (including orthopedic, visual, hearing, speaking, mental and multiple disability as well as people with chronic illness) was $14.3 \%$, unemployment rate was reported as $85.7 \%$. According to the Parliamentary Research Commission Report (March, 2020), conducted by the Grand National Assembly of Turkey (Parliament), and looking at the specific data on autism, there are 34.589 individuals with autism in Turkey. In the 2018-19 academic year, 3,422 students with autism received education through inclusion. According to the report mentioned, the number of institutions providing special education and rehabilitation services in 2019 is 2603; the number of students with autism studying in these institutions is 15,354. The statistics showed that 144 high school students with autism applied to a nation-wide university entrance exam in 2019 and only 17 students were placed in higher education institutions. The employment rate of registered people with ASD is $0.02 \%$, while the non-employment rate is 0.03 (TBMM, Parliamentary Research Commission Report, 2020). The statistics can make sense within the big picture; 2.528.031 students applied to the university exam (OSYM, 2019) and the employment rate was $46.1 \%$ in 2019 (TurkStat, 2019). Considering statistics on labor force participation, unemployment rates, working conditions, and the data specific to individuals with ASD in Turkey together a perspective can be obtained on the difficulties and obstacles that parents having children with ASD may encounter in working life. In this context, in-depth examination of the career adaptability of parents by qualitative research will provide a basis to determine their strengths and needs in terms of adaptability resources, and of proactive studies that may be carried out in this direction.

\section{Present Study}

Based on CCT (Savickas, 1997, 2005), the aim of the present study was to explore qualitatively career adaptability of Turkish parents of children with ASD. To obtain a deeper understanding of career adaptability of those parents, the study sought to answer the following research questions: (1) How do parents of children with ASD adapt to their career life? (2) What are their adaptability resources (career adaptabilities) in this process?

\section{Methodology}

\section{Research Design}

This study used a descriptive phenomenological method based on qualitative research design. The purpose of the descriptive phenomenological method is to define the experiences of individuals about the subject under investigation and to reveal the essence or essential structure of the experiences (Giorgi, 2009; Moustakas, 1994). Particularly, the descriptive phenomenological design focuses on the "essence" or "essential structure" of individuals' experiences regarding a particular phenomenon (Giorgi, 2009). Thus, the essence examined in this study was career adaptability of parents of children with ASD.

\section{Participants}

The study included 30 volunteer parents. Based on purposive sampling (Patton, 2014), the inclusion criteria were (a) having a child diagnosed with autism, (b) currently working in a job, (c) being a university graduate, and (d) spouses not divorced and living together. Aforementioned, the previous work indicated that career adaptability can change according to education level (e.g., Zacher, 2014a) and that one of the parents ends or disrupts their career to take care of the child (e.g., Olsson \& Hwang, 2006; Rosenzweig et al., 2002). Hence, the inclusion criteria was determined to reduce any confounding roles of these variables to understand the topic.

Table 1 summarized the characteristics of the participants. The participants consisted of 18 fathers and 12 mothers; 12 of the participants were couples and the remaining six participants were fathers whose wives did not take part in the study. Participants' ages range from 26-45 years $(M=35.67, S D=4.72)$. The gender of children of the participants were $54 \%(n=13)$ male and $46 \%(n=11)$ female. The ages of the children varied between 4-14 years old. 
Table 1 Demographic characteristics of the participants and their children

\begin{tabular}{|c|c|c|c|c|c|c|c|}
\hline & \multirow[t]{2}{*}{ Gender } & \multirow[t]{2}{*}{ Age } & \multirow[t]{2}{*}{ Job } & \multirow[t]{2}{*}{ W. Hours } & \multicolumn{3}{|l|}{ Child } \\
\hline & & & & & Gender & Age & Diagnosis \\
\hline P1 & Male & 32 & Police & $42 \mathrm{~h}$ & Boy & 8 & Mild \\
\hline $\mathrm{P} 2$ & Female & 29 & Nurse & $60 \mathrm{~h}$ & & & \\
\hline P3 & Female & 26 & Weaver & $45 \mathrm{~h}$ & Boy & 5 & Mild \\
\hline P4 & Male & 40 & Teacher & $50 \mathrm{~h}$ & Girl & 11 & Mild \\
\hline P5 & Female & 37 & Teacher & $22 \mathrm{~h}$ & & & \\
\hline P6 & Male & 37 & Business Administrator & $45 \mathrm{~h}$ & Girl & 11 & Mild \\
\hline P7 & Male & 41 & Public Officer Specialist & $40 \mathrm{~h}$ & Girl & 14 & Mild \\
\hline P8 & Female & 40 & Academic & $25 \mathrm{~h}$ & & & \\
\hline P9 & Male & 36 & Computer Eng & $56 \mathrm{~h}$ & Boy & 11 & Mild \\
\hline P10 & Male & 44 & Teacher & $40 \mathrm{~h}$ & Girl & 6 & Mild \\
\hline P11 & Female & 38 & Teacher & $30 \mathrm{~h}$ & & & \\
\hline P12 & Male & 28 & Teacher & $36 \mathrm{~h}$ & Girl & 9 & Severe \\
\hline P13 & Male & 42 & Civil Eng & $60 \mathrm{~h}$ & Boy & 10 & Severe \\
\hline P14 & Female & 42 & Pharmacist & $45 \mathrm{~h}$ & & & \\
\hline P15 & Male & 33 & Research Assistant & $50 \mathrm{~h}$ & Boy & 12 & Mild \\
\hline P16 & Female & 32 & Research Assistant & $45 \mathrm{~h}$ & Girl & 12 & Mild \\
\hline P17 & Male & 30 & Teacher & $35 \mathrm{~h}$ & Boy & 8 & Mild \\
\hline P18 & Male & 36 & Architect-accountant & $45 \mathrm{~h}$ & Boy & 10 & Mild \\
\hline P19 & Female & 36 & Dentist & $40 \mathrm{~h}$ & Boy & 6 & Mild \\
\hline P20 & Male & 31 & Civil Eng & $45 \mathrm{~h}$ & Boy & 10 & Mild \\
\hline $\mathrm{P} 21$ & Male & 38 & Math. Teacher & 50 ours & Girl & 4 & Severe \\
\hline P22 & Female & 36 & Bank Clerk & $45 \mathrm{~h}$ & Girl & 11 & Mild \\
\hline 23 & Male & 37 & Crane Operator & $45 \mathrm{~h}$ & Girl & 6 & Mild \\
\hline P24 & Female & 32 & Doctor & $60 \mathrm{~h}$ & Boy & 12 & Mild \\
\hline P25 & Male & 32 & Topographical Eng & $45 \mathrm{~h}$ & Boy & 11 & Moderate \\
\hline P26 & Male & 45 & Doctor & $50 \mathrm{~h}$ & Boy & 8 & Severe \\
\hline P27 & Female & 35 & Academic & $45 \mathrm{~h}$ & & & \\
\hline P28 & Female & 32 & Music Teacher & $35 \mathrm{~h}$ & Girl & 5 & Moderate \\
\hline P29 & Female & 36 & Tailor & $45 \mathrm{~h}$ & Boy & 5 & Moderate \\
\hline P30 & Male & 37 & Primary School Teacher & $30 \mathrm{~h}$ & Girl & 9 & Severe \\
\hline
\end{tabular}

$66.6 \%(n=16)$ of the children were diagnosed with mild, $12.6 \%(n=3)$ moderate, $20.8 \%(n=5)$ severe autism.

\section{Data Collection}

To collect data, the semi-structured interview form, participant feedback form and researcher diary developed by the researchers were used. First, the interview questions were prepared within the framework of the CCT (Savickas, 2005) and the literature on career difficulties experienced by parents of children with ASD (e.g., Stoner \& Stoner, 2014, 2016). Then, the researchers requested opinions of four experts on the interview questions; two faculty members who work in career counseling and two from the special education field who have studies on autism. Based on the expert appraisal, the interview form was finalized by the researchers. Sample questions included: "Can you give information about your career and working life after your child was diagnosed with ASD?", "What do you think about your career options and alternatives?", "What obstacles have you faced during your working life?", "How do you deal with these?", and "What do you need for your career development?" Second, the Participant Feedback Form included open-ended questions to obtain the opinions of the participants about the interview. The sample questions included: "How do you evaluate the interview process in general?", "Was there any situation / question you were uncomfortable with during the interview?", "What insights did you gain about the subject after you have participated in the interview?" Third, the researcher conducting the interviews filled the Researcher Diary Form after each interview to obtain the first impression of the researcher. The sample questions included "How did you prepare for the interview?", "Generally speaking, what do you think about your interview?", "What were the prominent themes in the meeting?". 
The researchers prepared an interview protocol on how to conduct the interview and what will be considered during the interview process (Yıldırım \& Şimşek, 2016). In this protocol, it was stated that all interviews will be held by the second researcher, a maximum of three interviews on the same day, a minimum of four hours between interviews to listen to the participant actively and conduct the interviews more effectively, and sending the feedback form to the participants on the day following the interview. Later, a pilot application was made in line with this protocol. The first researcher verified the process by examining the interview transcription, which had been carried out as planned.

Prior to the data collection process, an approval from Hacettepe University Ethics Committee was obtained. After that, the researchers contacted psychologists/counselors in special education and rehabilitation centers in Ankara and Istanbul, explained the purpose of the research, and asked them to make an announcement to reach the prospective participants. The announcements were posted in the appropriate places in the institutions, sent to their e-mail addresses and mobile phones. Later, the second researcher contacted voluntary parents one by one by the phone; explained the purpose and method of the research and scheduled an appointment. The interviews were conducted face to face and online (via Zoom) between August and October 2020 and lasted around $40 \mathrm{~min}$. All were recorded. After each interview, the researcher who conducted the interviews filled the Researcher Diary. One day after the interview, the participant feedback form was sent to the participants to fill out. In total, 15 parents responded to the participant feedback form.

\section{Trustworthiness}

Trustworthiness is important as a substitute for validity and reliability in qualitative research (Patton, 2014). For credibility (or internal validity), long-term interaction (longterm study of both researchers in the area to be researched), depth-focused data collection (creating literature-based semi-structured questions), triangulation of data collection methods (semi-structured interview, participant feedback form etc.), having expert opinion (on interview questions) and participant confirmation (on transcripts) were ensured (Creswell, 2014; Yıldırım \& Şimşek, 2016). Researcher diary was used to control the subjectivity of the researcher in the data collection process, which is another precaution that can be taken in this context (Creswell, 2014); thus the researcher who conducted the interviews took notes of their experiences regarding the processes before and after each interview. For transferability (or external validity), the research process (design, preparation of questions, data collection process and data analysis) was described in detail; a purposeful sampling method was used and the data obtained from the participants were presented with direct quotations
(Creswell, 2014). For dependability (internal reliability) and confirmability (or external reliability), during the data collection process, in addition to participant and expert confirmation, the interview questions were formed based on theoretical baseline, and the findings obtained in the study were discussed in the light of the relevant literature (Patton, 2014).

\section{Data Analysis}

To analyze data, Colaizzi's (1978) seven-step method was used. First, in the "Familiarization" phase, one of the researchers transcribed all the interviews, and two researchers read these transcripts repeatedly again (Step-1). Then, the researchers came together and discussed important statements about career adaptability at the stage of "Identifying significant statements" (Step-2). In the "Formulating meanings" stage, they coded a randomly selected interview together by going through the significant statements they discussed in the previous stage to have a common perspective (Step-3). Hence, the researchers tried to identify expressions relevant to career adaptability. Afterwards, the researchers analyzed the remaining transcripts separately. The data analysis performed by each researcher was examined by the other researcher. In the fourth stage, "Clustering themes", the researchers came together again and discussed the codes and the themes that could explain the data at a general level and sub levels, and then clustered the themes (Step-4). In the fifth stage, "Developing an exhaustive description", the themes and subthemes formed were discussed within the CCT (Step-5), while the sixth stage, "Producing the fundamental structure", discussed how the findings could be presented within the relevant theoretical framework, how to give the flow and order, and end the analysis (Step-6). Finally, in the "Seeking verification of the fundamental structure" stage, the findings were sent to a sub-sample of 10 people for verification (Step-7). The Maxqda 20, a qualitative data analysis software, was used in the analysis of the data.

\section{Results}

The findings of this research revealed four main themes: (1) traumas/changes in work-life after ASD, (2) career adaptability, (3) influences of COVID-19 pandemic and (4) postinterview awareness. The first theme, traumas/changes in work-life after ASD indicated what kind of difficulties the participants experienced in their working life after their children were diagnosed with ASD, what changed and how the working life of the participants in general was affected by this situation. According to the findings, it was seen that the participants have difficulty in focusing on their work in the 
period after the diagnosis. P5 stated "In the early days, we were pretty devastated by the effect of the case. So as if life has stopped. I could not focus on my work, I could not focus on school, and things like that." P1 expressed "But in the first years I could not put my mind to work. It was always on my mind, so how will it be?" Under this theme, the participants also mentioned that they had to quit their jobs; for instance, "Naturally, my boss was getting worse and I had to quit..." (P10). P12 stated "When I first got the diagnosis, I had to quit." P19 stated "I decided to quit due to increasing problems". Some participants also mentioned that they had to change their jobs: "As I said, I closed my own workplace and started working with another pharmacist" (P15). "Then I found a workplace where I could work more comfortably and flexibly and started working there" (P10). Willingness to make changes in specialization fields was also emphasized; P28 said, "For example, the number of studies on families with autism is limited. That's why I'm trying to work on this subject too."

The second theme, career adaptability, retained its four dimensions: concern, control, curiosity and confidence. Concern sub-theme included codes about looking ahead and future plans. Thus, results indicated that the participants were thinking about their own career future. For example, P5 expressed "So maybe I will be an academic. I still have little hope." P10 stated "On the one hand, I am trying to improve my English. Because English is a must in our department, frankly." P11 said "England is one of the most influential places in this business. That's why we will sell everything here and settle there." It was seen that their future orientation was accompanied by hope. For example, P21 said "I will be promoted after a while where I work now, as experience is an important factor in engineering terms." P30 responded that "We will be more used to this life in the future." On the other hand, there were some situations where the participants were uninterested and hopeless about their careers. P23 expressed that "But it is a fact that I did not pursue a career as much as before." P25 said "Other than that I have no plan about advancing in the career or making room or making more money after finishing the expertise." P17 stated "I am very despondent." In addition, it was revealed that the diagnosis of autism affected the future career plans of the parents and made some changes. The idea of establishing one's own workplace was emphasized intensely. For example, P19 mentioned "I now thought of starting my own business and sustaining my career by setting my own working hours", while P26 said "It makes more sense to start my own business all around. Because I will be able to go home whenever I want..." It was seen that the participants were looking for more flexible and comfortable job opportunities as well as considering its salary. For example, P25 said “... my expectation is to work in a calm hospital." P26 said "When I saw a very different project, I wanted to work on that job even if it wasn't well paid. Right now, the financial return of a job is much more important." P2 also mentioned "After our child was diagnosed with autism, I decided to become a teacher. It was important due to both economic conditions and regular working hours." In general, according to the findings under this theme, it can be said that the participants have a perspective about their career futures, but this is mostly shaped by the need for job changes, comfortable working conditions, and starting their own business, as a result of their children's diagnosis. Therefore, it could be stated that career concern was affected by ASD rather than individuals' goals and wishes. For instance P24 stated that "To be honest, I do not know what will happen in the future. We are in serious uncertainty. So we don't know how this will happen." P13 said "I can't think much about my own future right now, frankly."

Control sub-theme included the codes mostly related to decision-making process and the relevant factors. First of all, the role of earning high income was mentioned frequently. For instance, $\mathrm{P} 4$ mentioned, "To me, materiality is very important. In other words, making money comes first." while P22 said that "Financial opportunities are important for me." It was seen that staying close to the child was also taken into account while considering career options and making decisions. P1 said "Sometimes we say let's go away from here, but here is the situation of our child that obstructs us. So we plan everything accordingly." P2 said "It is impossible for us to think without taking this situation into account". P23 stated "...I cannot go abroad (because of their child's situation). This prevents me from working in the international arena." In addition, parents emphasized being persistent regarding their career life. P17 reported that "I can say work, work, and work. So working hard no matter what", P23 said that "This helped me learn not to give up in any job. These are also the most important reasons for my success in my career." Moreover, it was seen that the participants were thoughtful about their career plans. For instance, P13 said "...it is certain that a difficult process awaits us. So we have to consider him in our next decisions", P14 said "I always keep all the possibilities in a corner of my mind." However, many participants stated that as a result of ASD, they gave up or returned many opportunities related to their career or postponed them to a later time. For instance, P3 said "Child's care, education, problems, etc. That's why I can't spare a lot of time for myself and my career." P11 said "So myself, maybe years ago I was going abroad alone, but I gave up. Now, if I have such an opportunity, I cannot go even if I want to. Indeed, I don't go." P24 expressed "for him I reject offers to go and work in more distant places." P6 said "Then we gave up completely because of our child with autism." Overall, it could be inferred that the contents regarding decisionmaking processes were shaped around ASD. While giving up their previous career goals and own priorities about the 
career future, it could be said that the characteristics of the participants such as persistence and thoughtfulness were linked with having to work for the future of the child.

Curiosity sub-theme encompassed the contents regarding career exploration and self-exploration. The participants' career opportunities and their views on discovering these opportunities were revealed regarding career exploration. For instance, P10 mentioned, "I always try to attend courses. Currently, the number of online courses has increased due to the pandemic. I'm trying to take them." P25 stated, "Actually, I have many alternatives. So doing a minor in another department or working in a private hospital or to be a head doctor. Also, passing to university and becoming an academic. These are all options." P22 said, "As a mathematics teacher, alternatives are working in the public or private sector. I'm doing both of these because I'm trying to make more money." Regarding self-exploration, on the other hand, it was seen that very few participants focused on discovering their own characteristics. For instance P14 emphasized that "I make a decision considering my personality traits, interests and values." It could be summarized that although the participants explored career alternatives for financial reasons due to ASD diagnosis, they did it without self-exploration, almost.

Confidence sub-theme included the codes of difficulties at work, expectations from work, coping strategies and career supports. Participants frequently emphasized the difficulties they encountered in working life after diagnosis of ASD. For example, P17 stated, “...We suddenly have to go to the rehab center in a hurry. Such situations of course compel us at work." It is revealed that the employer attitudes added to these difficulties. P10 mentioned that "I sometimes come late to work in the morning because of sleeplessness, the boss is getting nervous." P15 said, "The boss and employee relationship, working hours, salaries, commuting, etc. are all difficulties for me." Similarly, P19 mentioned that "Although my boss tried to understand my situation, he gradually started to cause problems later when I had to go home." Accordingly, participants generally addressed some work expectations such as more time, salary, and flexibility. For instance P20 said "I need to continue my doctorate so I have to have more time to be able to do this", P22 said "Most of the time, I don't even have time to sleep..." P28 said "As I mentioned, my basic need is time." Regarding economic gain, P15 said "Of course there are also economic conditions. It would be better for me if I could earn a little more." P13 said “...We are having financial difficulties.” It was also seen that the participants needed better working conditions, providing flexibility. For instance P25 said "Just a little quieter working life, that's enough." The participants stated some strategies to cope with the problems such as reducing their working hours ("I reduced my teaching hours at school", P6), establishing a self-employment ("I try to arrange my working hours in my own private clinic by getting more experienced", P20), and doing additional work ("Here I sometimes do additional work, such as stage consultant and so on. We manage it this way", P17). The participants finally emphasized their career supports such as their spouses ("My spouse has an important role in my life." P9; "...my spouse supports me a lot." P5), their family of origin ("We were so relieved that our child built a good relationship with my mother. In this way, both my spouse and I can engage in our own work." P27), and caregivers ("We also have a nursing sister at home. It's better than" P16).

Although it was not the primary aim of the study, the participants also mentioned how COVID-19 affected their work life, indicating either positive or negative influences. It was seen that the participants who were adversely affected by the pandemic experienced loss of income especially. For instance P24 said "It impacted us, obviously because jobs fell by half. Of course, when you don't work, there is no income." P7 also expressed "It affected, of course. So first of all, jobs are down." The results also showed that some parents experienced positive sides of the pandemic. For instance, "For now, this situation is positive for us. I can work in two places at the same time." (P13), "After the outbreak of corona, we started to work from home. It has been very good for me" (P10). The fourth and final theme of the study included post-interview awareness of the participants. The findings indicated that the participants neglected themselves after the diagnosis of ASD and focused more on their children. For instance P26 said "It was a different interview for me. As families with autism, we constantly participate in interviews and studies about our children. But we also need this kind of study, which is about us." P27 said "I missed having a talk with someone about myself. I noticed this actually. That's why the interview was good for me."

\section{Discussion}

This study aimed to examine the career adaptability of parents having children with ASD in depth. The analysis revealed four main themes: traumas/changes in work-life after ASD, career adaptability, corona experiences and post-interview awareness.According to the findings, it was seen that the parents experienced traumas/changes in work life in the period after the diagnosis of ASD, first. This situation can be explained by the fact that ASD continues lifelong (Shattuck et al., 2007), and children with autism, in particular, are dependent on parents for their care and needs (Turnbull et al, 2015). This requires parents to make arrangements in their own lives, including work life. The current findings were consistent with the previous studies showed that the child's care and needs make it difficult for both parents to work full-time (Myers 
et al., 2009; Rosenzweig et al., 2008), and that parents often experienced changing their job, quit their job or not take a job (Baker \& Drapela, 2010; DePape \& Lindsay, 2015; Üstüner-Top, 2009). In addition, even some studies showed that the parents quit their job after the diagnosis of ASD and started to work in a field related to ASD (Zhang et al., 2015), which was somewhat mentioned by the current results.

The findings included the contents regarding career adaptability and its four dimensions: concern, control, curiosity, and confidence. Career adaptability was underlined as an important coping skill that parents of children with disabilities need in the context of life regulation skills (Ginevra et al., 2018). Concern is associated with individuals having future plans, high levels of hope and optimism, and positive feelings for the future (Savickas, 2005; Savickas \& Porfeli, 2012). In this study, it was seen that the participants focused on the future, yet emphasized the changes in their future career plans along with the diagnosis, at the same time. This could be explained by the fact that due to the high cost of access to services, such as treatment for a child diagnosed with ASD (Ardıç, 2013; Fletcher et al., 2012), parents have to make more effort to earn a better income and they need to work in different sectors (Knapp et al., 2009). The relevant literature also showed that parents look ahead to the future and wonder what will happen in the future for their child with ASD (Hock et al., 2012) and thus plan their future by considering their child's situation (Cassidy, 2008; Ludlow et al., 2012). In addition, parents can develop positive expectations for future (Fredrickson, 2004) and optimistic attitudes about the future thanks to positive reframing strategies (Lambert et al., 2009), and thus act by planning the future (Lutz et al., 2012), which was addressed by the current findings, also. Not surprisingly, the results also indicated that the participants emphasized lack of concern and lack of hope, which supported the previous findings noted that these parents have lower levels of hope than parents of a child with typical development (Ergüner-Tekinalp \& Akkök 2004; Montes \& Halterman, 2007). It can be said that the reason for this situation could be uncertainty in the nature of ASD; its causes and treatment have not been clearly determined (APA, 2013), which also creates stress and anxiety for parents (Liao \& Wei, 2011; Uskun \& Gundogar, 2010), resulting in ambivalent feelings for their own career future. It could be also tentatively inferred that parents looked ahead, planned their future and even changed their previous career plans to respond to their child's needs, which might also result in lack of concern and hope about their own career future, considering that they had to give up their previous career aspirations and goals.
Control is associated with individuals' having decisionmaking skills about their future and feeling responsible for their own career development (Savickas, 2005), which was supported with the current sample. Consistent with the present findings, the existing literature indicated that parents need to consider their children with ASD while making decisions about their own lives (Demirhan, 2018; Lewis et al., 2000; Whiting, 2014) as their lives are shaped by their children with ASD (Hock et al., 2012; Shattuck et al., 2007). Parents' feeling of responsibility for their career development (Järbrink et al., 2003; Whiting, 2014) was also regarded as related to their children's needs including medical, educational, social and financial support (Brown et al., 2011; Cavkaytar et al., 2008). The previous work demonstrated that parents strived consistently and decisively for the development of both themselves and their children, and their belief and motivation levels were high for having better conditions (Ardıç \& Olçay, 2020); they were persistent for solving problems (Altiere \& Kluge, 2009). On the other hand, the findings somewhat addressing lack of sense of control could be explained by the fact that parents have difficulty in maintaining the balance between work life and family life, and they are indecisive about how to act (Lewis et al., 2000), and might have to postpone or leave their careers (Rosenzweig et al., 2002, 2008).

Curiosity is associated with being open to new experiences, being willing to explore different options, being inquisitive and finding a suitable job (Savickas, 2005; Savickas \& Porfeli, 2012). Due to the changing characteristics and needs of children with ASD over time, parents tend to explore new options in their careers; in order for their children to benefit more effectively from services such as education and health, they need more income and therefore they may change their field of work (Croen et al., 2006; Liptak et al., 2006), even with a higher probability of changing their job compared to parents of children with typical development (e.g., Montes \& Halterman, 2008). Also, they need to be more flexible in their job to allocate their time and energy to their family (Matthews et al., 2011). Thus, it could be said that the parents are inclined to engage in career exploration as a result of their concern about their career futures (career concern) due to reasons such as spending more time for their children or having more flexible working hours. However, according to the findings obtained from the research, the parents expressed low self-exploration. This could be due to the fact that parents attached more importance to job characteristics (working hours, wages, flexibility, etc.) rather than individual characteristics such as their interests and abilities.

Confidence is related to having self- efficacious beliefs to overcome career obstacles (Savickas, 2013). Difficulties experienced by the participants in working life (not getting time off from work, lack of understanding of employers, 
etc.) and expectations from work (such as time, high wages, flexible working hours) were emphasized. In the literature, it was revealed that parents face career barriers such as not being able to work in every job due to the care needs of their children (Gray, 2002); having difficulty in continuing to work (Myers et al., 2009); a decrease in working hours (Baker \& Drapela, 2010) and therefore a lower income (Cidav et al., 2012). The previous studies also showed that parents of children with special needs, such as ASD, experienced more work-family conflict (Al-Yagon \& Cinamon, 2008) and needed more workplace flexibility (Brennan et al., 2007; George et al., 2008). Thus, as shown in the results, parents used some coping strategies to overcome those difficulties, which might imply their being self-confident (e.g., Gray, 2002; Savickas, 2013). In addition, parents' perceiving social support from their spouses and families (e.g., Hastings \& Brown, 2002; Matthews et al., 2010) seemed to be highly influential in their career development.

According to the results, some participants were adversely affected by the corona pandemic due to reasons such as loss of income and difficult working conditions, yet some were positively affected by the opportunity to work from home and flexible working hours. It was reported that the world economy is expected to shrink by at least $2.4 \%$ due to Covid19 outbreak (OECD, 2020). In Turkey, it was stated that about 6 million employees might be directly or indirectly affected negatively from the COVID-19 (Yükseler, 2020). Moreover, it was stated that COVID 19 had negative effects on both the children with special needs (Fegert et al., 2020; Hassiotis et al., 2020) and their parents (Chang \& Satako, 2020; Hassiotis et al., 2020; UNESCO, 2020) in many aspects, especially in terms of health and economy, which would create pressure and stress on parents (Karip, 2020). In addition to this, the transition to a distance/ remote working system influenced some parents positively. The advantages of working from home/remotely have been reported such as saving time, being energetic, flexibility, comfort, running home and work-related activities together (Dockery \& Bawa, 2020; Mustajab et al., 2020; Rubin \& Wessely, 2020), which were all parents of children with ASD dreamed about. Considering that some sectors such as information and communication technologies, medical (e.g. Dockery \& Bawa, 2020) were positively affected by the crisis, it could be assumed that the participants who have those professions (pharmacist, computer engineer, teachers etc.) in this study might be utilized new working conditions more due to the pandemic.

Finally, it was seen that the participants also became more self-aware after the interview. In the literature, it was stated that parents of children diagnosed with ASD put this condition at the center of their lives by postponing their needs (Nealy et al., 2012; Özşenol et al., 2003) and this might negatively affect their mental health (Kaytez et al., 2015; Risdal \& Singer, 2004). Therefore, it was emphasized that the awareness raised as a result of the interviews with parents had a positive effect on them (Wright et al., 2010). It can be assumed that social support (Cobb, 1976), which is regarded as taking care of and making individuals feel valued, caused this awareness. Similarly, it was seen that the studies conducted with parents of children with ASD in Turkey helped them to adapt to the challenging situation they are in (Top, 2009; Ünlüer, 2009), which was somewhat provided in this study.

\section{Implications}

This study has some implications for theory, research, and practice. Theoretically, the concept of career adaptability was verified with parents of children with $\mathrm{ASD}$, retaining four dimensions as concern, control, curiosity, and confidence as well as its qualitative descriptors within the framework of the CCT. Hence, this research contributed to the theoretical literature by supporting the findings on career adaptability of individuals with individual differences and their parents (e.g., Baker \& Drapela, 2010; Montes \& Halterman, 2008; Rosenzweig et al., 2008). For research, the study provided a deep and comprehensive examination of adaptability resources of parents of children with ASD by using descriptive phenomenological research design. Rather than quantitatively scoring the four dimensions of career adaptability on a scale, the study revealed, by content analysis, which skills emerged, which needs and requirements pointed which dimension more, and what aspects needed to support each career adaptability dimension. However, longitudinal studies can also be conducted about the changes experienced by the parents during the pre-diagnosis process, in the early stages of diagnosis, and with children's age regarding career adaptability and its resources. In addition, qualitative research can examine the relationships between employers and parents in working life, deeply. What kind of support employers need to support the working life of parents, how to advocate for rights of those parents, how to improve the laws, how the laws will support the employer in a way that allows these parents to stay in working life and to feel successful can be demonstrated in depth with qualitative research. For practice, the results of the study implied career support for parents of ASD children, especially fostering their some specific adaptability resources. The research indicated that there is a need for practices related to concern, which is the first dimension of career adaptability, to support hope levels to have an optimistic view of the future and to control sub-dimension to support decision-making skills and to increase the sense of control over career futures. In addition, career intervention can be carried out to enhance self-exploration regarding curiosity sub-dimension, to help parents to discover themselves as well as career options. Moreover, career support programs to teach alternative 
coping strategies can be provided, regarding confidence sub-dimension. Along with these efforts, legal regulations such as Disabilities Act No. 5378 in Turkey and "Disability Inclusion Strategy and Action Plan" prepared by ILO should be reviewed and improved for ensuring the protection of the work life of individuals with disabilities and their parents. At this point, it is possible to state that there is a need for legal regulations made by the Ministry of Labor and Social Security to establish units where parents can receive career support services, to provide career development support services under Turkish Employment Office (TEO), and to provide free services by career counselors in local organizations such as community centers and municipalities. These all refer to development of policies for supporting career development and work life of parents of children with ASD.

\section{Limitations and Future Directions}

Although this study contributes to the literature on career adaptability, it has some limitations. First, the participants consisted of a relatively privileged group of university graduates, although it was the result of mindful effort about to minimize the differences between the participants by using criterion sampling in order to better understand the subject, considering that the diversification in job and career opportunities depending on the level of education may add other confounding variables in understanding the career adaptability of parents of children with autism. It was assumed that examining career adaptability of a parent with autism in such a group that may be more advantageous in finding a job and changing jobs depending on the level of education might provide preliminary findings to examine the issue for parents who have more disadvantaged conditions. In future studies, differences in career adaptability of the parents can be examined according to the various characteristics of them (level of education, job, and socio-economic status) and the diagnosis level of their children (mild, moderate, and severe). Second, conducting online interviews with some participants can be seen as another limitation of the study. To reduce the effect of this condition on the study, all interviews were conducted by the same researcher in line with the validity-reliability methods in qualitative studies, and the interviews were carried out within the framework of the interview protocol prepared by the researchers. Lastly, this study was conducted with a relatively small sample group $(n=30)$, although it was underlined that qualitative studies aim at gathering in-depth information on the subject studied, and their intent is not to generalize the findings (e.g., Patton, 2014). Especially considering that obtaining rich information and reaching saturation is important in qualitative studies, since there is no rule of thumb for sample size (Creswell, 2014); hence, this number can be seen as sufficient.
Author Contributions The first author designed the study topic and the research methodology in collaboration with the second author. The second author made semi-structural interviews to ensure internal validity. The first author validated the pilot interview and reviewed all process to ensure that second author follow research protocol by collecting data to ensure validity of the qualitative study. The first and second authors analyzed data together. Both authors wrote the article collaboratively and prepare the manuscript according to the guidelines of the journal.

Data Availability Not applicable as qualitative data includes some personal information about the participants.

Code Availability Not applicable.

\section{Declarations}

Conflict of Interest/Competing Interests On behalf of all authors, the corresponding author states that there is no conflict of interest.

Ethics Approvals and Consent to Participate All the procedures that involved human participants were conducted in accordance with the ethical standards of the institutional and/or national research committee as well as the 1964 Helsinki declaration and its later amendments or comparable ethical standards. The IRB approval was obtained from Hacettepe University Ethics Committee (REF: 76942594 $600 / 00001171353$ ). Informed consent was obtained from participants.

\section{References}

Altiere, M. J., \& Von Kluge, S. (2009). Family functioning and coping behaviors in parents of children with autism. Journal of Child and Family Studies, 18(1), 83-92. https://doi.org/10.1007/ s10826-008-9209-y

Al-Yagon, M., \& Cinamon, R. G. (2008). Work-family relations among mothers of children with learning disorders. European Journal of Special Needs Education, 23(2), 91-107. https://doi.org/10. 1080/08856250801946202

American Psychiatric Association. (2013). Diagnostic and statistical manual of mental disorders (DSM-5®). American Psychiatric Pub.

Ardıç, A., \& Olçay, S. (2020). Investigation of the relationship between the burnout level of parents of children with autism spectrum disorder (asd) and asd symptom level and family needs by regression analysis. Education and Science, 1-13. https://doi.org/10. 15390/EB.2020.8980

Ardıç, A. (2013). Effects of psycho-educational group program on the some psychological variables of parents whose the children with autistic spectrum disorders (Unpublished Master's thesis). Anadolu University, Ankara

Baker, D. L., \& Drapela, L. A. (2010). Mostly the mother: Concentration of adverse employment effects on mothers of children with autism. The Social Science Journal, 47(3), 578-592. https://doi. org/10.1016/j.soscij.2010.01.013

Baker, K., \& Pope, J. (2009). Employment and work disability in systemic lupus erythematosus: A systematic review. Rheumatology, 48(3), 281-284. https://doi.org/10.1093/rheumatology/ken477

Bimrose, J., \& Hearne, L. (2012). Resilience and career adaptability: Qualitative studies of adult career counseling. Journal of 
Vocational Behavior, 81(3), 338-344. https://doi.org/10.1016/j. jvb.2012.08.002

Brennan, E. M., Rosenzweig, J. M., Ogilvie, A. M., Wuest, L., \& Shindo, A. A. (2007). Employed parents of children with mental health disorders: Achieving work-family fit, flexibility, and role quality. Families in Society, 88(1), 115-123. https://doi.org/10. 1606/1044-3894.3598

Brown, H. K., Ouellette-Kuntz, H., Hunter, D., Kelley, E., Cobigo, V., \& Lam, M. (2011). Beyond an autism diagnosis: Children's functional independence and parents' unmet needs. Journal of Autism and Developmental Disorders, 41(10), 1291-1302. https://doi. org/10.1007/s10803-010-1148-y

Buyukgoze-Kavas, A., Duffy, R. D., \& Douglass, R. P. (2015). Exploring links between career adaptability, work volition, and wellbeing among Turkish students. Journal of Vocational Behavior, 90, 122-131. https://doi.org/10.1016/j.jvb.2015.08.006

Cassidy, J. (2008). The nature of the child's ties. In J. Cassidy \& P. R. Shaver (Eds.), Handbook of attachment: Theory, research, and clinical applications (pp. 3-22). The Guilford Press.

Cavkaytar, A., Batu, S., \& Cetin, O. B. (2008). Perspectives of Turkish mothers on having a child with developmental disabilities. International Journal of Special Education, 23(2), 101-109.

Chan, S. H., Mai, X., Kuok, O. M., \& Kong, S. H. (2016). The influence of satisfaction and promotability on the relation between career adaptability and turnover intentions. Journal of Vocational Behavior, 92, 167-175. https://doi.org/10.1016/j.jvb.2015.12.003

Chang, G.C.\& Satako, Y. (2020). How are countries addressing the Covid-19 challenges in education? A snapshot of policy measures. Retrieved from https://gemreportunesco.wordpress.com/ 2020/03/24/how-are-countries-addressing-thecovid-19-chall enges-in-education-a-snapshot-of-policy-measures. Accessed Jan 5, 2020

Cidav, Z., Marcus, S. C., \& Mandell, D. S. (2012). Implications of childhood autism for parental employment and earnings. Pediatrics, 129(4), 617-623. https://doi.org/10.1542/peds.2011-2700

Cobb, S. (1976). Social support as a moderator of life stress. Psychosomatic Medicine, 38(5), 300-314. https://doi.org/10.1097/00006 842-197609000-00003

Coetzee, M., \& Harry, N. (2014). Emotional intelligence as a predictor of employees' career adaptability. Journal of Vocational Behavior, 84(1), 90-97. https://doi.org/10.1016/j.jvb.2013.09.001

Colaizzi, P. (1978). Psychological research as a phenomenologist views it. In Valle, R. S. \& King, M. (1978). Existential phenomenological alternatives for psychology. Open University Press.

Creswell, J. W. (2014). A concise introduction to mixed methods research. SAGE Publications.

Croen, L. A., Najjar, D. V., Ray, G. T., Lotspeich, L., \& Bernal, P. (2006). A comparison of health care utilization and costs of children with and without autism spectrum disorders in a large group-model health plan. Pediatrics, 118(4), e1203-e1211. https://doi.org/10.1542/peds.2006-0127

Demirhan, A. (2018). Performance of machine learning methods in determining the autism spectrum disorder cases. Mugla Journal of Science and Technology, 4(1), 79-84. https://doi.org/10. 22531/muglajsci.422546

DePape, A. M., \& Lindsay, S. (2015). Parents' experiences of caring for a child with autism spectrum disorder. Qualitative Health Research, 25(4), 569-583. https://doi.org/10.1177/1049732314 552455

Dockery, M., \& Bawa, S. (2020). Working from Home in the COVID-19 Lockdown. Bentley: Bankwest Curtin Economics Centre.

Duarte, C. S., Bordin, I. A., Yazigi, L., \& Mooney, J. (2005). Factors associated with stress in mothers of children with autism. Autism, 9(4), 416-427. https://doi.org/10.1177/1362361305056081
Ergüner-Tekinalp, B., \& Akkök, F. (2004). The effects of a coping skills training program on the coping skills, hopelessness, and stress levels of mothers of children with autism. International Journal for the Advancement of Counselling, 26(3), 257-269. https://doi. org/10.1023/B:ADCO.0000035529.92256.0d

EuroStat, 2018. Quality issues regarding the measurement of working time with the Labour Force Survey (LFS). Retrieved from https:// ec.europa.eu/eurostat/documents /7870049/8734970/KS-FT17-005-EN-N.pdf/0eb7518a-d0ca-45c4-942e-49107724e09a. Accessed June 6, 2020

Fegert, J. M., Vitiello, B., Plener, P. L., \& Clemens, V. (2020). Challenges and burden of the Coronavirus 2019 (COVID-19) pandemic for child and adolescent mental health: A narrative review to highlight clinical and research needs in the acute phase and the long return to normality. Child and Adolescent Psychiatry and Mental Health, 14, 1-11. https://doi.org/10.1186/ s13034-020-00329-3

Fiori, M., Bollmann, G., \& Rossier, J. (2015). Exploring the path through which career adaptability increases job satisfaction and lowers job stress: The role of affect. Journal of Vocational Behavior, 91, 113-121. https://doi.org/10.1016/j.jvb.2015.08.010

Fletcher, P. C., Markoulakis, R., \& Bryden, P. J. (2012). The costs of caring for a child with an autism spectrum disorder. Issues in Comprehensive Pediatric Nursing, 35(1), 45-69. https://doi.org/ $10.3109 / 01460862.2012 .645407$

Fredrickson, B. L. (2004). The broaden-and-build theory of positive emotions. Philosophical Transactions of the Royal Society of London. Series B: Biological Sciences, 359(1449), 1367-1377. https://doi.org/10.1007/s10803-011-1269-y

Freedman, B. H., Kalb, L. G., Zablotsky, B., \& Stuart, E. A. (2012). Relationship status among parents of children with autism spectrum disorders: A population-based study. Journal of Autism and Developmental Disorders, 42(4), 539-548. https://doi.org/ 10.1007/s10803-011-1269-y

George, A., Vickers, M. H., Wilkes, L., \& Barton, B. (2008). Working and caring for a child with chronic illness: Challenges in maintaining employment. Employee Responsibilities and Rights Journal, 20(3), 165-176. https://doi.org/10.1007/s10672-008-9065-3

Ginevra, M. C., Magnano, P., Lodi, E., Annovazzi, C., Camussi, E., Patrizi, P., \& Nota, L. (2018). The role of career adaptability and courage on life satisfaction in adolescence. Journal of Adolescence, 62, 1-8. https://doi.org/10.1016/j.adolescence.2017. 11.002

Giorgi, A. (2009). The descriptive phenomenological method in psychology: A modified Husserlian approach. Duquesne University Press.

Gladding, S. T. (2014). Family therapy: History, theory, and practice. Pearson Higher Ed.

Gray, D. E. (2002). 'Everybody just freezes. Everybody is just embarrassed': Felt and enacted stigma among parents of children with high functioning autism. Sociology of Health \& Illness, 24(6), 734-749. https://doi.org/10.1111/14679566.00316

Hartley, S. L., Barker, E. T., Seltzer, M. M., Floyd, F., Greenberg, J., Orsmond, G., \& Bolt, D. (2010). The relative risk and timing of divorce in families of children with an autism spectrum disorder. Journal of Family Psychology, 24, 449-457. https://doi.org/10. 1037/a0019847

Hartley, S. L., DaWalt, L. S., \& Schultz, H. M. (2017). Daily couple experiences and parent affect in families of children with versus without autism. Journal of Autism and Developmental Disorders, 47(6), 1645-1658. https://doi.org/10.1007/s10803-017-3088-2

Hartung, P. J., \& Cadaret, M. C. (2017). Career adaptability: Changing self and situation for satisfaction and success. In Psychology of career adaptability, employability and resilience (pp. 15-28). Springer. 
Hassiotis, A., Ali, A., Courtemanche, A., Lunsky, Y., McIntyre, L. L., Napolitamo, D., \& Werner, S. (2020). In the time of the pandemic: Safeguarding people with developmental disabilities against the impact of coronavirus. Journal of Mental Health Research in Intellectual Disabilities, 13(2), 63-65. https://doi. org/10.10 80/19315864.2020.1756080

Hastings, R. P., \& Brown, T. (2002). Behavior problems of children with autism, parental self-efficacy, and mental health. American Journal on Mental Retardation, 107(3), 222-232. https://doi.org/ 10.1352/0895-8017(2002)107\%3c0222:BPOCWA\%3e2.0.CO;2

Hayes, S. A., \& Watson, S. L. (2013). The impact of parenting stress: A meta-analysis of studies comparing the experience of parenting stress in parents of children with and without autism spectrum disorder. Journal of Autism and Developmental Disorders, 43(3), 629-642. https://doi.org/10.1007/s10803-012-1604-y

Hirschi, A. (2010). The role of chance events in the school-to-work transition: The influence of demographic, personality and career development variables. Journal of Vocational Behavior, 77(1), 39-49. https://doi.org/10.1016/j.jvb.2010.02.002

Hirschi, A., \& Valero, D. (2015). Career adaptability profiles and their relationship to adaptivity and adapting. Journal of Vocational Behavior, 88, 220-229. https://doi.org/10.1016/j.jvb.2015.03.010

Hirschi, A., Herrmann, A., \& Keller, A. C. (2015). Career adaptivity, adaptability, and adapting: A conceptual and empirical investigation. Journal of Vocational Behavior, 87(0), 1-10. https://doi.org/ 10.1016/j.jvb.2014.11.008

Hock, R. M., Timm, T. M., \& Ramisch, J. L. (2012). Parenting children with autism spectrum disorders: A crucible for couple relationships. Child \& Family Social Work, 17(4), 406-415. https://doi. org/10.1111/j.1365-2206.2011.00794.x

İkizoğlu, M. (2005). Özürlü, özürlü ailesi ve toplum ilişkisi. Ufkun Ötesi Bilim Dergisi, 1, 47-60.

Järbrink, K., Fombonne, E., \& Knapp, M. (2003). Measuring the parental, service and cost impacts of children with autistic spectrum disorder: A pilot study. Journal of Autism and Developmental Disorders, 33(4), 395-402. https://doi.org/10.1023/A:10250 58711465

Johnston, C. S. (2016). A systematic review of the career adaptability literature and future outlook. Journal of Career Assessment, 1 , 1-28. https://doi.org/10.1177/1069072716679921

Johnston, D. W., \& Lee, W. S. (2013). Extra status and extra stress: Are promotions good for us? ILR Review, 66(1), 32-54. https://doi. org/10.1177/001979391306600102

Johnston, C. S., Luciano, E. C., Maggiori, C., Ruch, W., \& Rossier, J. (2013). Validation of the German version of the Career AdaptAbilities Scale and its relation to orientations to happiness and work stress. Journal of Vocational Behavior, 83(3), 295-304. https://doi.org/10.1016/j.jvb.2013.06.002

Karip, E. (2020). COVID-19: Okulların Kapatılması ve Sonrası. TEDMEM. https://tedmem.org/vurus/covid-19-okullarin-kapatilmasive-sonrasi. Retrieved from https://tedmem.org/vurus/covid-19okullarin-kapatilmasi-ve-sonrasi Accessed June 16, 2020

Kaytez, N., Durualp, E., \& Kadan, G. (2015). Evaluation of requirements and stress levels of the families having disabled child. Journal of Research in Education and Teaching, 4(1), 197-214.

Klehe, U. C., Zikic, J., Van Vianen, A. E., \& De Pater, I. E. (2011). Career adaptability, turnover and loyalty during organizational downsizing. Journal of Vocational Behavior, 79(1), 217-229. https://doi.org/10.1016/j.jvb.2011.01.004

Knapp, C., Madden, V., Wang, H., Sloyer, P., \& Shenkman, E. (2011). Internet use and eHealth literacy of low-income parents whose children have special health care needs. Journal of Medical Internet Research, 13(3), e75. https://doi.org/10.2196/jmir.1697

Knapp, M., Romeo, R., \& Beecham, J. (2009). Economic cost of autism in the UK. Autism, 13(3), 317-336. https://doi.org/10. $1177 / 1362361309104246$
Lambert, N. M., Graham, S. M., Fincham, F. D., \& Stillman, T. F. (2009). A changed perspective: How gratitude can affect sense of coherence through positive reframing. The Journal of Positive Psychology, 4(6), 461-470. https://doi.org/10.1080/17439 760903157182

Lecavalier, L., Leone, S., \& Wiltz, J. (2006). The impact of behaviour problems on caregiver stress in young people with autism spectrum disorders. Journal of Intellectual Disability Research, 50(3), 172-183. https://doi.org/10.1111/j.1365-2788.2005. 00732.x

Lewis, S., Kagan, C., \& Heaton, P. (2000). Dual-earner parents with disabled children: Family patterns for working and caring. Journal of Family Issues, 21(8), 1031-1060. https://doi.org/10.1177/ 019251300021008005

Li, Y., Guan, Y., Wang, F., Zhou, X., Guo, K., Jiang, P., \& Fang, Z. (2015). Big-five personality and BIS/BAS traits as predictors of career exploration: The mediation role of career adaptability. Journal of Vocational Behavior, 89, 39-45. https://doi.org/ 10.10 16/j.jvb.2015.04.006

Liao, K. Y., \& Wei, M. (2011). Intolerance of uncertainty, depression, and anxiety: The moderating and mediating roles of rumination. Journal of Clinical Psychology, 67(12), 1220-1239. https://doi. org/10.1002/jclp.20846

Liptak, G. S., Stuart, T., \& Auinger, P. (2006). Health care utilization and expenditures for children with autism: Data from US national samples. Journal of Autism and Developmental Disorders, 36(7), 871-879. https://doi.org/10.1007/s10803-006-0119-9

Ludlow, A., Skelly, C., \& Rohleder, P. (2012). Challenges faced by parents of children diagnosed with autism spectrum disorder. Journal of Health Psychology, 17(5), 702-711. https://doi.org/ $10.1177 / 1359105311422955$

Lutz, H. R., Patterson, B. J., \& Klein, J. (2012). Coping with autism: A journey toward adaptation. Journal of Pediatric Nursing, 27(3), 206-213. https://doi.org/10.1016/j.pedn.2011.03.013

Matthews, R. A., Bulger, C. A., \& Barnes-Farrell, J. L. (2010). Work social supports, role stressors, and work-family conflict: The moderating effect of age. Journal of Vocational Behavior, 76(1), 78-90. https://doi.org/10.1016/j.jvb.2009.06.011

Matthews, R. A., Booth, S. M., Taylor, C. F., \& Martin, T. (2011). A qualitative examination of the work-family interface: Parents of children with autism spectrum disorder. Journal of Vocational Behavior, 79(3), 625-639. https://doi.org/10.1016/j.jvb.2011. 04.010

McArdle, S., Waters, L., Briscoe, J. P., \& Hall, D. T. T. (2007). Employability during unemployment: Adaptability, career identity and human and social capital. Journal of Vocational Behavior, 71(2), 247-264. https://doi.org/10.1016/j.jvb.2007.06.003

Meral, B. F., \& Cavkaytar, A. (2012). A study on social support perception of parents who have children with autism. International Journal on New Trends in Education and Their Implications, 3, 124-135.

Montes, G., \& Halterman, J. S. (2006). Characteristics of school-age children with autism. Journal of Developmental \& Behavioral Pediatrics, 27(5), 379-385.

Montes, G., \& Halterman, J. S. (2007). Psychological functioning and coping among mothers of children with autism: A populationbased study. Pediatrics, 119(5), e1040-e1046. https://doi.org/10. 1542/peds.2006-2819

Montes, G., \& Halterman, J. S. (2008). Association of childhood autism spectrum disorders and loss of family income. Pediatrics, 121(4), 821-826. https://doi.org/10.1542/peds.2007-1594

Moustakas, C.E. (1994). Phenomenological Research Methods. SAGE Publications.

Mustajab, D., Bauw, A., Rasyid, A., Irawan, A., Akbar, M. A., \& Hamid, M. A. (2020). Working from home phenomenon as an effort to prevent COVID-19 attacks and its impacts on work 
productivity. TIJAB (The International Journal of Applied Business), 4(1), 13-21. https://doi.org/10.20473/tijab.V4.I1.2020. 13-21

Myers, B. J., Mackintosh, V. H., \& Goin-Kochel, R. P. (2009). "My greatest joy and my greatest heart ache:" Parents' own words on how having a child in the autism spectrum has affected their lives and their families' lives. Research in Autism Spectrum Disorders, 3(3), 670-684. https://doi.org/10.1016/j.rasd.2009.01.004

Nealy, C. E., O'Hare, L., Powers, J. D., \& Swick, D. C. (2012). The impact of autism spectrum disorders on the family: A qualitative study of mothers' perspectives. Journal of Family Social Work, 15(3), 187-201. https://doi.org/10.1080/10522158.2012.675624

Ocampo, A. C. G., Restubog, S. L. D., Liwag, M. E., Wang, L., \& Petelczyc, C. (2018). My spouse is my strength: Interactive effects of perceived organizational and spousal support in predicting career adaptability and career outcomes. Journal of Vocational Behavior, 108, 165-177. https://doi.org/10.1016/j. jvb.2018.08.001

Öğrenci Seçme ve Yerleştirme Merkezi (ÖSYM). 2019 YKS Yerleştirme Sonuçlarına İlişkin Sayısal Bilgiler [2019 University Exam Placement Statistics]. Retrieved from https://dokum an.osym.gov.tr/pdfdokuman/2019/YKS/sayisalbilgiler06082019. pdf Accessed Nov 5, 2021

Organization for Economic Co-operation and Development. (2017). Employment Outlok 2017. Retrieved from https://www.oecd. org/turkey/Employment-Outlook-Turkey-EN.pdf Accessed Sept 20,2020

Organization for Economic Co-operation and Development. (2020). Economic Outlook. Retrieved from http://www.oecd.org/econo mic-outlook/march-2021/ Accessed Sept 20, 2020

Orsmond, G. I., \& Seltzer, M. M. (2007). Siblings of individuals with autism spectrum disorders across the life course. Mental Retardation and Developmental Disabilities Research Reviews, 13(4), 313-320. https://doi.org/10.1002/mrdd.20171

Özşenol, F., Işıkhan, V., Unay, B., Aydın, H. I., Akın, R., \& Gökcay, E. (2003). The evaluation of family functions of families with handicapped children. Gülhane Medical Journal, 45(2), 156-164.

Pajic, S., Ulceluse, M., Kismihók, G., Mol, S. T., \& den Hartog, D. N. (2018). Antecedents of job search self-efficacy of Syrian refugees in Greece and the Netherlands. Journal of Vocational Behavior, 105, 159-172. https://doi.org/10.1016/j.jvb.2017.11.001

Patton, M. Q. (2014). Qualitative research \& evaluation methods (4th Ed.). SAGE Publications.

Pelchat, D., Lefebvre, H., \& Perreault, M. (2003). Differences and similarities between mothers' and fathers' experiences of parenting a child with a disability. Journal of Child Health Care, 7(4), 231-247. https://doi.org/10.1177/13674935030074001

Risdal, D., \& Singer, G. H. (2004). Marital adjustment in parents of children with disabilities: A historical review and meta-analysis. Research and Practice for Persons with Severe Disabilities, 29(2), 95-103. https://doi.org/10.2511/rpsd.29.2.95

Rosenzweig, J. M., Brennan, E. M., \& Ogilvie, A. M. (2002). Workfamily fit: Voices of parents of children with emotional and behavioral disorders. Social Work, 47(4), 415-424. https://doi. org/10.1093/sw/47.4.415

Rosenzweig, J. M., Brennan, E. M., Huffstutter, K., \& Bradley, J. R. (2008). Child care and employed parents of children with emotional or behavioral disorders. Journal of Emotional and Behavioral Disorders, 16(2), 78-89. https://doi.org/10.1177/10634 26607312538

Rubin, G. J. \& Wessely, S. (2020). The psychological effects of quarantining a city. British Medical Journal, 368. https://doi.org/10. 1136/bmj.m313

Savickas, M. L. (1997). Career adaptability: An integrative construct for life-span, lifespace theory. The Career Development
Quarterly, 45(3), 247-259. https://doi.org/10.1002/j.2161-0045. 1997.tb00469.x

Savickas, M. L. (2005). The theory and practice of career construction. In S. D. Brown \& R. W. Lent (Eds.), Career development and counseling: Putting theory and research to work (pp. 42-70). Wiley.

Savickas, M. L., \& Porfeli, E. J. (2012). The Career adapt-abilities scale: Construction, reliability, and measurement equivalence across 13 countries. Journal of Vocational Behavior, 80(3), 744-747. https://doi.org/10.1016/j.jvb.2012.01.011

Savickas, M. L. (2013). Career construction theory and practice. In: R. W. Lent ve S. D. Brown (Eds.), Career development and counseling: Putting theory and research to work (ss. 144-180). Wiley.

Shattuck, P. T., Seltzer, M. M., Greenberg, J. S., Orsmond, G. I., Bolt, D., Kring, S., \& Lord, C. (2007). Change in autism symptoms and maladaptive behaviors in adolescents and adults with an autism spectrum disorder. Journal of Autism and Developmental Disorders, 37(9), 1735-1747. https://doi.org/10.1007/ s10803-006-0307-7

Sibunruang, H., Garcia, P. R. J. M., \& Tolentino, L. R. (2016). Ingratiation as an adapting strategy: Its relationship with career adaptability, career sponsorship, and promotability. Journal of Vocational Behavior, 92, 135-144. https://doi.org/10.1016/j. jvb.2015.11.011

Stoner, C. R., \& Stoner, J. B. (2014). How can we make this work? Understanding and responding to working parents of children with autism. Business Horizons, 57, 85-95. https://doi.org/10. 1016/j.bushor.2013.10.002

Stoner, J. B., \& Stoner, C. R. (2016). Career disruption: The impact of transitioning from a full-time career professional to the primary caregiver of a child with autism spectrum disorder. Focus on Autism and Other Developmental Disabilities, 31(2), 104-114. https://doi.org/10.1177/1088357614528798

The Grand National Assembly of Turkey. (2020). Parliamentary Research Commission Report. Retrieved from https://www. tbmm.gov.tr/develop/owa/tbmminternet.anasayfa Accessed Jan 20, 2021

Top, F. Ü. (2009). The evaluation of the problems and psychological states of the families who have autistic children: A qualitative Research. Journal of Child, 9(1), 34-42.

Turkish Statistical Institute. (2010). Turkey Survey on Problems and Expectations of Disabled People 2010. Retrieved from https:// www.tuik.gov.tr/Home/Index Accessed January 20, 2021

Turkish Statistical Institute. (2019). Labour Force Statistics. Retrieved from https://data.tuik.gov.tr/Bulten/Index?p=IsgucuIstatistikleri-Mayis-2019-30691 Accessed Nov 5, 2021

Turkish Statistical Institute. (2020a). Labour Force Statistics. Retrieved from https://data.tuik.gov.tr/Bulten/Index?p= Labour-Force-Statistics-2020-37484 Accessed Jan 20, 2021

Turkish Statistical Institute. (2020b). Income and Living Conditions Survey. Retrieved from https://data.tuik.gov.tr/Bulten/ Index $\mathrm{p}=$ =Income-and-Living-Conditions-Survey-2019-33820 Accessed Jan 20, 2021

Turnbull, A., Turnbull, H. R., Erwin, E. J., \& Shogren, K. A. (2015). Families, professionals, and exceptionality: Positive outcomes through partnerships and trust. Pearson.

UNESCO. (2020). COVID-19 educational disruption and responses. Retrieved from https://en.unesco.org/covid19/educationrespon se Accessed June 20, 2020

Ünlüer, E. (2009). Investigation of relationship between perceived social support and hopelessness level of the mothers who have the child with autism between the age 2-6 (Unpublished Master's thesis). Marmara University, İstanbul.

Uskun, E., \& Gundogar, D. (2010). The levels of stress, depression and anxiety of parents of disabled children in Turkey. 
Disability and Rehabilitation, 32(23), 1917-1927. https://doi. org/10.3109/09638281003763804

Walsh, C. E., Mulder, E., \& Tudor, M. E. (2013). Predictors of parent stress in a sample of children with ASD: Pain, problem behavior, and parental coping. Research in Autism Spectrum Disorders, 7(2), 256-264. https://doi.org/10.1016/j.rasd.2012.08.010

Walsh, J. A., Vida, M. D., \& Rutherford, M. D. (2014). Strategies for perceiving facial expressions in adults with autism spectrum disorder. Journal of Autism and Developmental Disorders, 44, 1018-1026. https://doi.org/10.1007/s10803-013-1953-1

Whiting, M. (2014). Support requirements of parents caring for a child with disability and complex health needs. Nursing Children and Young People, 26(4), 24-27. https://doi.org/10.7748/ncyp2014. 05.26.4.24.e389

Wright, K. D., Stewart, S. H., \& Finley, G. A. (2010). When are parents helpful? A randomized clinical trial of the efficacy of parental presence for pediatric anesthesia. Canadian Journal of Anesthesia/journal Canadien D'anesthésie, 57(8), 751-758. https://doi. org/10.1007/s12630-010-9333-1

Xie, B., Xia, M., Xin, X., \& Zhou, W. (2016). Linking calling to work engagement and subjective career success: The perspective of career construction theory. Journal of Vocational Behavior, 94, 70-78. https://doi.org/10.1016/j.jvb.2016.02.011

Yang, X., Feng, Y., Meng, Y., \& Qiu, Y. (2019). Career adaptability, work engagement, and employee well-being among chinese employees: The role of guanxi. Frontiers in Psychology, 10, 1029. https://doi.org/10.3389/fpsyg.2019.01029

Yıldırım, A. \& Şimşek, H. (2016). Sosyal bilimlerde nitel araştırma yöntemleri. Seçkin Yayınları.
Youssef, C. M., \& Luthans, F. (2007). Positive organizational behavior in the workplace: The impact of hope, optimism, and resilience. Journal of Management, 33(5), 774-800. https://doi.org/10.1177/ 0149206307305562

Yükseler, Z. (2020). Koronavirüs (COVID-19) Salgınının İstihdam ve Büyümeye Etkisi. Retrieved from https://www.researchgate.net/ publication/340511319 Accessed January 20, 2021

Zacher, H. (2014a). Career adaptability predicts subjective career success above and beyond personality traits and core self-evaluations. Journal of Vocational Behavior, 84, 21-30. https://doi.org/ $10.1016 /$ j.jvb.2013.10.002

Zacher, H. (2014b). Individual difference predictors of change in career adaptability over time. Journal of Vocational Behavior, 84, 188198. https://doi.org/10.1016/j.jvb.2014.01.001

Zacher, H., Ambiel, R. A., \& Noronha, A. P. P. (2015). Career adaptability and career entrenchment. Journal of Vocational Behavior, 88, 164-173. https://doi.org/10.1016/j.jvb.2015.03.006

Zhang, W., Yan, T. T., Barriball, K. L., While, A. E., \& Liu, X. H. (2015). Post-traumatic growth in mothers of children with autism: A phenomenological study. Autism, 19(1), 29-37. https:// doi.org/10.1177/1362361313509732

Publisher's Note Springer Nature remains neutral with regard to jurisdictional claims in published maps and institutional affiliations. 